\title{
Com és que cada vegada tenim menys alumnes a les classes?
}

Com a col-lectiu professional hem d'opinar sobre aquesta progressiva minva que notem a les nostres classes, amb la finalitat de fer-hi alguna cosa: ja sigui actuar en els nostres centres, o bé proposar als polítics responsables de l'educació algunes mesures que creguem necessàries per frenar aquesta tendència.

La disminució del nombre d'alumnes que estudien ciències és una tendència comuna dels països més desenvolupats. Algunes dades d'aquesta minva a Catalunya, proporcionades per la Generalitat, són aquestes (fig. 1):

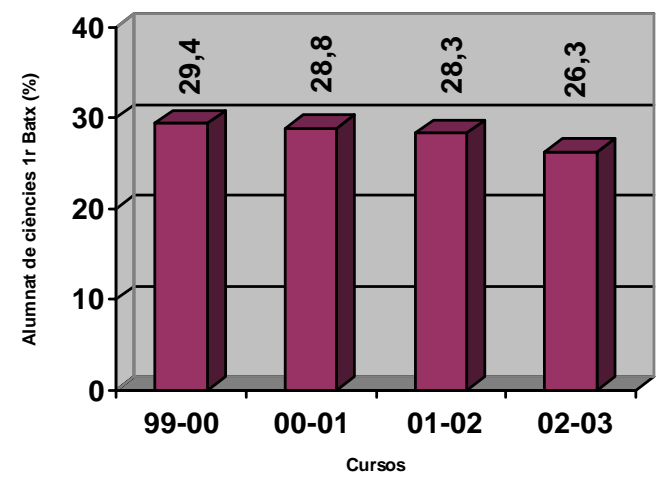

Fig. 1. Evolució del percentatge de l'alumnat de primer de Batxillerat que cursa la modalitat de Ciències de la Naturalesa i de la Salut a Catalunya durant els darrers cursos. (Font: www.gencat.net)
Podria semblar que en una societat que depèn tant de la ciència i de la tècnica, els estudis científics haurien de resultar atractius per als estudiants. En canvi, ja veiem que no és així.

Aquest és un problema greu, ja que al món s'han anat tancant facultats de ciències. Professionalment, doncs, ens ha de preocupar, ja que ens hi va la feina. Hem de fer alguna cosa per comprendre'n les causes i actuar per capgirar-ne la tendència.

Quines poden ser les causes d'aquest desinterès? Quines les hem de buscar en l'àmbit social més general? Quines les hem d'atribuir a característiques de la nostra feina que no satisfan les expectatives dels joves?

La disminució de persones amb suficient formació científica pot produir problemes en l'economia del país fàcils d'imaginar. Però com capgirar la tendència? Què podem fer-hi des de la nostra tasca professional? Què hi haurien de fer els responsables de la política educativa del país?

Envia les teves aportacions al debat a la nostra adreça:

revista.ciencies@uab.es 